\title{
Metaphors of mental illness: a corpus-based approach analysing first-person accounts of patients and mental health professionals ${ }^{1}$
}

Metáforas de la enfermedad mental: análisis de un corpus de testimonios en primera persona de pacientes y profesionales de la salud mental

MARTA COLL-FLORIT

UNIVERSITAT OBERTA DE CATALUNYA

ORCID: https://orcid.org/0000-0002-8636-458X

ANTONI OLIVER

UNIVERSITAT OBERTA DE CATALUNYA

ORCID: https://orcid.org/0000-0001-8399-3770

SAlVADOR Climent

UNIVERSITAT OBERTA DE CATALUNYA

ORCID: https://orcid.org/0000-0002-3462-3551

\begin{abstract}
In this paper we describe the building, manual annotation and analysis of a balanced corpus to assess conceptual metaphors on mental illness as used in Spanish blogger writing by patients and mental health professionals. The corpus was structured as eight subgroups: four patient subgroups (composed of persons who declared having been diagnosed with major depression, schizophrenia, bipolar disorder, or obsessive-compulsive disorder) and four mental health professional subgroups (psychiatrists, psychologists, social
\end{abstract}

1 This research was conducted in the framework of MOMENT: Metaphors of severe mental disorders. Discourse analysis of affected people and mental health professionals, a project funded by the Spanish National Research Agency (Agencia Estatal de Investigación, AEI) and the European Regional Development Fund (ERDF), within the Spanish Government's National Programme for Research Aimed at the Challenges of Society. Ref. FFI2017-86969-R (AEI/ERDF, EU). We would like to thank the two anonymous reviewers whose comments and suggestions helped to improve this manuscript. 
educators, nurses). The quantitative analysis identified similarities and differences between groups regarding the volume of metaphors produced and the topics linguistically expressed through metaphors. The most frequent metaphors used by each major group, patients and professionals, were qualitatively analysed, with the principal findings showing a set of source domains used to conceptualize all four severe mental disorders, thus pointing to a common conceptualization of mental suffering irrespective of the specific diagnosis, and two major types of metaphors, WAR and JOURNEY, used by all subgroups of patients and professionals to talk about their first-hand experiences.

Key words: conceptual metaphor, mental illness, blogs, corpus.

RESUMEN: En este artículo describimos la construcción, anotación manual y análisis de un corpus equilibrado para evaluar las metáforas conceptuales sobre la enfermedad mental usadas en blogs españoles por pacientes y profesionales de la salud mental. El corpus se estructuró en ocho subgrupos: cuatro subgrupos de pacientes (personas que declararon haber sido diagnosticadas con depresión grave, esquizofrenia, trastorno bipolar o trastorno obsesivo-compulsivo) y cuatro subgrupos de profesionales de la salud mental (psiquiatras, psicólogos, educadores sociales, enfermeros). El análisis cuantitativo identificó similitudes y diferencias entre los grupos en cuanto al volumen de metáforas producidas y los temas expresados mediante metáforas. Asimismo, las metáforas más frecuentes se analizaron cualitativamente. Los principales resultados mostraron un conjunto de dominios origen utilizados para conceptualizar todos los cuatro trastornos mentales graves, apuntando así a una conceptualización común del sufrimiento mental, independientemente del diagnóstico específico, y dos tipos principales de metáforas, GUERRA y VIAJE, utilizadas por todos los subgrupos de pacientes y profesionales para hablar de sus experiencias en primera persona.

Palabras clave: metáfora conceptual, enfermedad mental, blogs, corpus.

\section{INTRODUCTION}

Adopting a corpus-based approach, this paper examines the most frequent conceptual metaphors used in mental health discourses in online blogs written in Spanish. More specifically, we analyse first-person accounts of people with a severe mental disorder diagnosis and mental health professionals. This study is part of a research project titled MOMENT: Metaphors of Severe Mental Disorders (Coll-Florit et al., 2018), whose primary aim is to study metaphor in mental health discourses in social media. The research relies on a multidisciplinary research team with extensive experience in applied linguistics and in several mental health fields, including psychology, social work and medical anthropology.

The conceptual metaphor theory (CMT), initially developed by Lakoff and Johnson (1980), posits that metaphor is so pervasive in ordinary daily life that our conceptual system is largely metaphorical in nature (Lakoff and Johnson, 1980: 3). According to the CMT, «metaphor enables us to think and talk about abstract, complex, subjective and/or poorly delineated areas of experience in terms of concrete, simpler, 
physical and/or better delineated areas of experience, often connected with our own bodies» (Semino, 2008: 30). For instance, it is very common to refer to arguments in terms of a war or fight (1) (examples by Lakoff and Johnson, 1980: 4). Note that conceptual metaphors (CMs) are abstract constructs that may be linguistically instantiated in multiple metaphorical expressions (MEs), i.e., MEs are specific linguistic cases of a $\mathrm{CM}^{2}$
CM: ARGUMENT IS WAR
ME: a. Your claims are indefensible.
b. His criticisms were right on target.
c. I've never won an argument with him.

A key CMT notion is associated with highlighting some concepts while hiding others; for instance, "ARGUMENT IS WAR highlights the competitive, aggressive and confrontational aspects of arguments and hides their cooperative, constructive aspects» (Semino, 2008: 33). Consequently, the linguistic use of different CMs to refer to a given area of experience may reveal different conceptualizations or ways of understanding the experience. This is why CM analysis is widely used to detect implicit ideas and assumptions in discourse.

Numerous studies have analysed the use of CMs in the discourse of physical illnesses, above all cancer (Gibbs \& Franks, 2002; Gustafsson et al., 2020; Hommerberg et al., 2020; Magaña \& Matlock, 2018; Navarro i Ferrando, 2017, 2021; Reisfield \& Wilson, 2004; Semino et al., 2017, 2018), and other conditions such as stroke (Boylstein et al., 2007) and diabetes (Goering, 2015). However, less attention has been paid to CMs in the field of mental health, especially with regard to the analysis of discourses published on the internet. As Kotliar (2016: 1203) points out, «despite the plethora of studies on illness and the web, research about online expressions of mental illness is scarce».

The main objective of the research described in this paper was, therefore, to build, annotate and analyse a corpus of first-person narratives on mental health published in blogs. Our particular focus was people diagnosed with one of the four most common severe mental disorders: major depression, schizophrenia, bipolar disorder and obsessivecompulsive disorder (OCD) (World Health Organization, 2018). Moreover, we analyse blogs written by people working in one of the four key mental health areas: psychiatry, psychology, nursing and social education. The main objective was to identify and analyse the predominant metaphors used to talk about mental illness and related experiences, as well as the most frequent metaphors used to conceptualize mental health professional practice. In addition, we were interested in making intergroup analyses for patients vs professionals, as well as intragroup analysis, to identify possible similarities and differences between and within groups.

The rest of this paper is divided into five sections. Section 2 reviews the literature on metaphor and mental health; Section 3 describes the corpus building and annotation methods used to detect and code metaphors; Sections 4 and 5 present the general quantitative analysis and the qualitative analyses, respectively; and, finally, Section 6 presents our overall conclusions.

\section{STATE OF THE ART ON METAPHOR AND MENTAL HEALTH}

\footnotetext{
2 CMs are conventionally formulated as [TARGET DOMAN] IS [SOURCE DOMAIN], in capitals. Likewise, metaphorically used words are highlighted in bold in the examples.
} 
Previous studies that have analysed CMs in the field of mental health have focused primarily on depression. Thus, a considerable body of literature has been published on metaphors of depression extracted from different types of corpora, such as therapy session recordings (McMullen \& Conway, 2002), interviews with people who have experienced depression (Charteris-Black, 2012), radio broadcasts (Semino, 2008), animation films (Fahlenbrach, 2017; Forceville \& Paling, 2018), press articles (Reali et al., 2016), fiction and nonfiction books (Demjén, 2011; Reali et al., 2016; Schoeneman et al., 2004) and, recently, blogs (Coll-Florit et al., 2021). Also worthy of mention, although based on a qualitative and non-corpus approach, is the seminal work on metaphor and depression by Barcelona (1986).

However, few studies have investigated metaphors used by patients with other severe mental disorders. For instance, Demjén et al. (2019) studied metaphor in firstperson accounts of voice-hearing by people with schizophrenia, while Coll-Florit et al. (2019) analysed documentaries which featured first-person accounts by both patients and mental health professionals. With regard to OCD discourses, the most notable studies were those carried out by Knapton (2016) and Knapton \& Rundblad (2018), who analysed a corpus of patient interviews. As for bipolar disorder, the study of metaphor as used in relation to this disorder is practically non-existent (see the work by Shoeneman et al, 2012).

At this point, it is worth mentioning the large and growing body of psycholinguistics and neurolinguistics literature indicating that individuals diagnosed with schizophrenia exhibit impairments in their cognitive and linguistic abilities, especially in aspects related to semantics and pragmatics (an exhaustive review on this topic is provided by Rosseti et al., 2018). In any case, it is important to note that most of those studies dealt with schizophrenia and metaphor comprehension, while studies of schizophrenia and metaphor production continue to be scant. Lastly, the use of figurative language in people with a neurological degenerative condition of dementia has also been studied, although in this case studies tend as well to focus on their comprehension ability, as pointed out by Varela Suarez (2020).

In relation to the discourse of mental health professionals, previous studies have focused on metaphor use in psychotherapy settings (cf. systematic reviews by McMullen, 2008; Mould et al. 2010; and Tay, 2016), highlighting its usefulness as a tool to facilitate communication between patient and therapist. Its use by mindfulness instructors has been studied as well (Silvestre-Lopez, 2016). However, the spontaneous elicitation of metaphors in first-person accounts by these professionals is very scarce; for instance, a study worth mentioning is Climent \& Coll-Florit (2017), who studied the role of metaphor in psychiatric discourses on schizophrenia by analyzing a documentary about this mental disorder including interviews with psychiatrists. Likewise, aside from Coll-Florit et al. (2019), as far as we are aware, there are no studies that integrate an analysis of discourses by patients with a severe mental health disorder and the mental health professionals who assess and treat them. While such comparative studies have been conducted for nonmental health illnesses such as cancer (Semino et al., 2017, 2018), this has been far less the case in the mental health field. The present work, as part of the larger MOMENT PROJECT: Metaphors of Severe Mental Disorders (Coll-Florit et al., 2018), aims to help bridge this gap.

\section{CORPUS BUILDING AND ANNOTATION METHOD}

This section presents in detail all the steps and criteria followed to build our corpus (Section 3.1) and to detect and annotate metaphors (Section 3.2). 


\subsection{CORPUS BUILDING}

Our research was based on blogs written in Spanish. The following steps were taken to identify suitable blogs for study: (a) all websites of mental health patient organizations headquartered in Spain were reviewed to detect blogs promoted or recommended by these organizations; (b) personal blogs written by patients and mental health professionals were located via Google searches conducted using keywords related to severe mental disorders; and (c) by means of virtual snowballing (O'Brien \& Clark, 2012; Kotliar, 2016), all blogrolls and webrings of sources identified in steps (a) and (b) were checked to identify further mental health blogs.

The criteria to select and include retrieved blogs in the corpus were as follows: (a) the authors of the blogs explicitly self-identified as having a severe mental disorder (schizophrenia, bipolar disorder, major depression or OCD) or as professionals working in mental health (psychiatrist, psychologist, nurse or social educator), hereinafter labelled, for convenience sake, patients and professionals; (b) the blogs were written in the first person, either by patients narrating their experiences of life with their mental disorder or by mental health professionals narrating their experience of treating mental disorders (i.e., blogs with an educational or informative focus were excluded); (c) the blogs were written in Spanish and published in Spain; and (d) the blogs had to be publicly available and not require a password or login, following the ethical principles detailed below.

Applying these inclusion criteria, a corpus was built that initially consisted of seventy-three patient blogs and twenty-two mental health professional blogs (total ninetyfive blogs and 3,539 posts), corresponding to a period of approximately ten years (June 2007 to March 2018, the date this study started). All posts were next manually reviewed in order to select only those that explicitly discussed, in the first person, the lived experience (patients) or the treatment experience (mental health professionals) of the mental disorder (e.g., posts in which a book or film was recommended were excluded). The final corpus consisted of a total of 919,910 words belonging to 1,315 posts. Table 1 shows the blog distribution and number of words for each of the eight analysed subgroups (four mental health disorder subgroups and four professional subgroups).

Table 1. Distribution of blogs and words in the MOMENT corpus

\begin{tabular}{|l|l|l|l|}
\hline \multicolumn{2}{|c|}{ Patients } & \multicolumn{2}{c|}{ Professionals } \\
\hline $\begin{array}{l}\text { Severe mental disorders } \\
\text { (blogs, n) }\end{array}$ & $\begin{array}{l}\text { Words } \\
\text { (n) }\end{array}$ & $\begin{array}{l}\text { Professionals } \\
\text { (blogs, n) }\end{array}$ & $\begin{array}{l}\text { Words } \\
\text { (n) }\end{array}$ \\
\hline Bipolar disorder (25) & 422,521 & Psychiatrist (8) & 52,013 \\
\hline Schizophrenia (22) & 157,939 & Psychologist (5) & 65,454 \\
\hline Major depression (21) & 79,452 & Nurse (4) & 51,648 \\
\hline Obsessive compulsive disorder (5) & 85,602 & Social educator (5) & 5,281 \\
\hline Total (73) & $\mathbf{7 4 5 , 5 1 4}$ & Total (22) & $\mathbf{1 7 4 , 3 9 6}$ \\
\hline
\end{tabular}


Once the texts were extracted, the corpus was computationally processed and anonymized. Texts were segmented into paragraphs and a code (ID) was added to identify the source blog and paragraph number.

Regarding ethical issues, a principle applied by many authors - Hookway (2008), Markham et al. (2012) and O'Brien \& Clark (2012) - is that indicated by Kotliar (2016: 1206): «materials that are posted online and [that] do not require subscription, login, or password access are intended to be publicly viewed, and therefore do not require the consent of their authors». Along the same lines, for the specific purpose of analysing metaphors in online narratives about diseases, Semino et al. (2018: 49) indicated that «there is some consensus that anything a person posts to a forum that is open to public view on the web can be used as research material without seeking informed consent from the individual contributor, as long as anonymity is fully preserved». These were the principles we adopted in our research, part of the MOMENT project that received the approval of the ethics committee of the Universitat Oberta de Catalunya.

\subsubsection{A balanced subcorpus for manual annotation}

The large MOMENT corpus of almost a million words will require, in a second stage of our project, the application of semiautomatic strategies of analysis, as done for other analyses of metaphors in corpora by Stefanowitsch (2006), Ogarkova \& Soriano (2014) and Semino et al. (2018), among others. However, manual annotation of a balanced subcorpus containing equivalent volumes of text for each analysed group was first necessary to identify predominant sets of CMs. The results of this entirely manual analysis are reported in this article.

A balanced subcorpus of 40,000 words was created by extracting 5,000-word samples for each of the eight analysed subgroups: 20,000 words reflecting the four patient types, and 20,000 words reflecting the four mental health professional types. This subcorpus was created automatically and randomly on the basis of text extraction paragraph by paragraph to ensure enough context for metaphor detection and interpretation. Using a randomization algorithm, for each iteration, a blog was selected at random and, for each blog, a paragraph was selected at random until 5,000 words were obtained in each of the eight analysed subgroups (total 40,000 words).

\subsection{CORPUS ANNOTATION}

This corpus was annotated using a method developed by and described in detail in Coll-Florit \& Climent (2019). Leaving aside simple intuitive annotation, existing methods for metaphor annotation can be divided into those performing metaphor detection and those performing metaphor labelling. Metaphor detection methods consist, basically, of the standard Metaphor Identification Procedure (MIP) (Pragglejaz Group, 2007) and its derivative called MIPVU (Steen et al. 2010b). These methods, essentially based on manual searching in dictionaries for all the words of a text in order to detect metaphorically used words, have the drawback that the underlying metaphors are not labelled in terms of a source domain and a target domain. Methods that label metaphors (Stefanowitsch 2006, Ogarkova \& Soriano 2014, Semino et al. 2018) are based on semiautomatic pre-detection of metaphorical candidates using keywords presumably associated with specific CMs.

Our goal was to annotate text with metaphor labelling. However, we did not use semiautomatic text preselection since we wanted to ensure that we located every possible metaphor related to mental health. This is why we developed a completely manual method 
for metaphor detection and labelling that ensured that the corpus was explored exhaustively. Moreover, following Ogarkova \& Soriano (2014), we decided to perform the annotation at two levels of abstraction: specific and generic. The former, closely linked to the linguistic expression in the text, captures in detail both the specific concepts and their adscription to the mental health field, while the latter should provide a semantic domain generalization that allows for comparison to previous studies and for optimal organization of outcomes.

We opted to search for and annotate two kinds of conceptual figures, namely, metaphors and metaphorical similes. This was because, following Steen et al. (2010b: 10-11), we assume cognitive cross-domain mapping in both cases. While in metaphors this is linguistically expressed indirectly, i.e., by means of metaphorically used language (2), in similes it is expressed overtly, typically by means of explicit comparative markers, e.g., "like" in English (3) (examples by Semino et al. 2018: 134, 282). From now on we will refer to both conceptual figures indistinctly as "metaphors", only drawing a distinction when necessary.

(2) I am humbled by courage and dignity of my patients on their final journey.

(3) Cancer is like a journey

Our method (Coll-Florit \& Climent, 2019) is organised in two main phases: metaphor hypothesizing and metaphor analysis. The metaphor hypothesizing phase is meant to overcome the problem of time inherent in the above-mentioned methods for manual detection, as a thorough lexicographical analysis of each word in a large corpus is not feasible in terms of time and human resources. In the metaphor analysis phase, hypotheses for metaphoricity are validated (or rejected) and clauses are annotated with domain formulae (target domain and source domain) at two levels.

Annotators are provided with a detailed annotation guide and a set of auxiliary documents, among them, most importantly, metaphor compendia. Metaphor identification is mainly based on dictionary checks (as in MIP and MIPVU) and metaphor labelling is based on metaphor compendia and metaphor formulation strategies (innovative features of our method). Compendia and formulation strategies aim to prevent divergence in annotator criteria so that the final results are both internally consistent as well as comparable to results reported in the literature. The annotation process is deterministic, taking place in steps following independent paths with no backtracking, as described below ${ }^{3}$.

\section{Phase 1. Candidate ME selection}

The annotator reads the sentence and its context to understand it and decide whether the sentence contains one or more candidate metaphorical clauses on the basis of two conditions: intended metaphoricity and thematic relevance. The annotator uses guidelines on how to hypothesize metaphoricity and a document defining mental health thematic fields (compiled from Climent \& Coll-Florit, 2017 and Coll-Florit et al., 2019). As a result of this stage, clauses with candidate MEs are extracted from the general text,

\footnotetext{
${ }^{3}$ The process described hereinafter is that used for conceptual metaphors, which are the vast majority of metaphorical expressions in our corpus. Metaphorical similes, which are the remainder, are treated differently in that instead of applying MIP, MIPVU is applied with the help of a list of simile markers in Spanish.
} 
resulting in a substantial reduction in the text to be analysed, and are annotated by thematic field.

\section{Phase 2. ME analysis: hypothesis verification and metaphor annotation}

Each candidate ME is analysed in a maximum of two steps. First, the candidate clause is checked against two metaphor compendia: a general-purpose compendium, the Master Metaphor List (Lakoff et al., 1991), and a specific compendium compiled from the extant literature for conceptual metaphor in mental health. These are structured repositories consisting of metaphor formulations (e.g. EMOTIONS ARE PHYSICAL FORCES) associated to representative examples (e.g. "He was struck by anger") organised by means of thematic categories (e.g. Emotions) (examples by Lakoff et al., 1991: 141). Hypothetical MEs are compared to examples and formulations included in the compendia and, if a possible match is found, then the MIP is applied to the clause in order to validate (or reject) metaphoricity (see Coll-Florit \& Climent, 2019: 54, 61-63). In positive cases, this procedure results in both metaphorical focus detection (metaphorically used words) and domain labelling as in the compendium.

If the candidate ME did not fit any metaphors in the compendia, a second step is employed: the MIP is first applied to the clause in order to detect the metaphorical focus if any. If metaphoricity is detected, then the domains are determined using metaphor formulation strategies (see Coll-Florit \& Climent, 2019: 54-58).

The metaphor formulation strategies used are three, as follows: (a) based on selectional preferences of a verb that is the metaphorical focus; (b) based on contrasting dictionary senses of the metaphorical focus; and (c) based on contrasting the dictionary meaning of the focus and its meaning on the text. The last two strategies differ only in whether or not there is a figurative meaning of the focus in the reference dictionary, i.e., on whether the metaphor is lexicalized (case b) or not (case c). Examples of strategies (a) and (c) are represented in (4) and (5):

(4) Mi baja autoestima me llevó a la depresión

My low self-esteem brought me into depression.

FOCUS: llevar (to bring)

Prototypical argument: PLACE

Argument in text: depresión (depression)

ANNOTATION AT THE SPECIFIC LEVEL: depresión $=$ destino $($ depression $=$ destination)

ANNOTATION AT THE GENERIC LEVEL: life of patient = journey

(5) Mi cabeza se ha convertido en una montaña rusa

My head has become a roller coaster

FOCUS: montaña rusa (roller coaster)

Basic meaning: an amusement ride

Figurative meaning: extreme mood swings

ANNOTATION AT THE SPECIFIC LEVEL: cabeza $=$ montaña rusa $($ head $=$ roller coaster)

ANNOTATION AT THE GENERIC LEVEL: disorder/mental health = descent/ascent

By this procedure, each sentence in the corpus with metaphoric content is annotated with its metaphorical focus (metaphorically used words) and each underlying metaphor is formulated for two levels of abstraction. For application of the MIP and domain formulation strategies, the dictionaries used as reference for our Spanish- 
language corpus are the CLAVE (Maldonado, 2012) as a usage dictionary and the Diccionario de la Lengua Española (DLE) (Real Academia Española, 2001) as an authoritative dictionary. Instructions are to use CLAVE preferably and to resort to DLE only in cases of doubt.

The validity and reliability of this annotation method has been empirically assessed in an inter-annotator agreement test, described in detail in Coll-Florit \& Climent (2019). Results showed a high degree of agreement (97.6\%; kappa value 0.79) regarding the annotation of metaphorically used words. These results are better than those reported for MIP (Praglejazz Group, 2007) and similar to those reported for MIPVU (Steen et al, 2010). In the labelling of the conceptual domains, agreement was reached in $71 \%$ of the cases and agreed in at least one domain in $87 \%$ of the cases.

The balanced corpus was annotated by three linguists, experts in conceptual metaphor theory. The linguists first analysed $20 \%$ of the 40,000 -word corpus $(8,000$ words, broken down into 1,000 words for each of the eight analysed groups) to detect possible incidents or doubtful cases and to unify criteria so as to ultimately ensure a consensus. The remaining $80 \%$ of the corpus was divided into three parts for annotation, each part by a single annotator, who subsequently reviewed the annotations of the other two annotators. Doubtful and complex cases were discussed in meetings between the three annotators until consensus was reached.

\section{GENERAL QUANTITATIVE RESULTS}

A total of 1,043 MEs were identified, 631 corresponding to patients and 412 to mental health professionals, with patients, therefore, using MEs to a greater degree than professionals.

Several corpus studies on metaphor have calculated metaphorical density (MD), i.e., the percentage of metaphorically used words relative to total words in a corpus. In relation to studies that counted all types of metaphors, Steen et al. (2010a: 790) reported an MD of 7.7\% for conversational texts and Knapton and Rundblad (2018: 400) reported an MD of $6.0 \%$ for texts written by people diagnosed with OCD. Semino et al (2017: 3), in a study of patients and professionals writing about cancer, calculated the MD of specific JOURNEY and WAR metaphors as ranging between $0.08 \%$ and $0.18 \%$, with patients outperforming professionals 1.7 to 1 for JOURNEY metaphors and 1.3 to 1 for WAR metaphors.

In our balanced corpus, MD was $3.15 \%$ for patients' texts and $2.06 \%$ for professionals' texts. Note that these figures correspond to mental health metaphors exclusively and, therefore, are not directly comparable to the above studies: not all types of metaphors are calculated - as done in Steen et al. (2010a) and Knapton \& Rundblad (2018) - and all types of mental health metaphors are included - not just JOURNEY and WAR metaphors as in Semino et al. (2017). Metaphors of mental health in our corpus, therefore, amount to just under half of all kinds of metaphors in comparable texts; we also corroborate Semino et al. (2017) in reporting that patients produce more metaphors than professionals in a ratio of around 1.5 to 1.

We applied a t-test (independent samples, two-tailed test) to calculate the statistical significance of differences between groups (patients vs professionals) in the volume of MEs. Results indicate that differences overall were not statistically significant $(p=0.129)$. However, when the data were analysed to focus on the type of metaphor by topic or thematic field, then statistically significant differences emerged. Table 2 shows the thematic distribution of identified MEs disaggregated by groups (patients and professionals) along with the level of statistical significance. 
Table 2. Differences between patients and professionals in ME volume by topic

\begin{tabular}{|l|l|l|l|}
\hline Thematic field & Patients, $\mathbf{n}$ & Professionals, n & p-value \\
\hline Severe mental disorder & 431 & 165 & 0.037 \\
\hline $\begin{array}{l}\text { Mental health medicine and } \\
\text { professional practice }\end{array}$ & 20 & 139 & 0.000 \\
\hline Communication and social context & 89 & 55 & 0.439 \\
\hline Thoughts and emotions & 91 & 53 & 0.269 \\
\hline Total & $\mathbf{6 3 1}$ & $\mathbf{4 1 2}$ & \\
\hline
\end{tabular}

Results show statistically significant differences between groups in the thematic areas of metaphors on severe mental disorders and metaphors on medicine and professional practice. In particular, patients produce more metaphors than professionals $(p=0.037)$ in the thematic area of severe mental disorder, which covers three target domains: MENTAL DISORDER, LIFE OF PATIENT and PATIENT (i.e., the disorder itself, the process of living with a mental disorder and the affected person as an individual, respectively). In contrast, professionals produce far more metaphors tan patients $(p=0.000)$ in the thematic area of medicine and professional practice, with three target domains: MEDICATION, MENTAL HEALTH PROFESSION and PROFESSIONAL (i.e., medication as a product, the practice of the profession in mental healthcare, and the professional as an individual, respectively). These two major groups of metaphors are qualitatively analysed in more depth in Section 5.

Regarding intragroup differences, Table 3 presents the ME volumes for each of the eight analysed subgroups. One-way ANOVA was used to detect whether there were differences between patient subgroups (people diagnosed with schizophrenia, bipolar disorder, major depression and OCD) and between professional subgroups (psychiatrists, psychologists, nurses and social educators).

The results show that there were no significant differences between patients according to mental health diagnosis $(\mathrm{p}=0.871)$, reinforcing the category of 'severe mental disorder' and demonstrating that all such patients make a similar use of metaphor to conceptualize their mental health experience. Moreover, as we will see in detail in Section 5, not only do we find similarities in the volume but also in the type of metaphors produced.

Table 3. Intragroup differences: ME volume patients and professional subgroups

\begin{tabular}{|l|l|l|c|}
\hline Main groups & Subgroups & ME volume, $\mathbf{n}$ & \multirow{2}{*}{ p-value } \\
\hline \multirow{4}{*}{ Patients } & Bipolar disorder & 169 & \multirow{3}{*}{0.871} \\
\cline { 2 - 3 } & Schizophrenia & 137 & \\
\cline { 2 - 3 } & Major depression & 150 & \\
\cline { 2 - 3 } & OCD & 175 & \multirow{3}{*}{0.066} \\
\hline \multirow{5}{*}{ Professionals } & Psychiatrist & 101 & \\
\cline { 2 - 3 } & Psychologist & 101 & \\
\cline { 2 - 3 } & Nurse & 65 & \\
\cline { 2 - 3 } & Social educator & 145 & \\
\hline
\end{tabular}

Regarding differences between mental health professional subgroups, the ANOVA test showed a considerable tendency towards significance $(p=0.066)$. To detect 
where differences lay, subsequent ad-hoc comparisons were performed using a t-test by pairs of professional profiles. Statistically significant differences were found between social educators vs nurses $(\mathrm{p}=0.015)$ in terms of producing the largest vs the smallest number of metaphors, respectively. In fact, within the mental health professions, those two careers can be viewed as being the furthest apart. Nurses have a medical background and so tend to focus more on physical issues (e.g., in the case of confinement to psychiatric units, nurses are responsible for monitoring patient medication); for this reason they probably have less need to talk about abstract concepts and, consequently, to use metaphor. Social educators, in contrast, usually adopt a more holistic and contextual approach, therefore they rely more frequently on metaphor to talk about abstract, intangible or theoretical concepts. No statistically significant differences were found for the other professional subgroups. The greatest similarity was between psychiatrists and psychologists, who produced exactly the same number of metaphors of mental health.

\section{QUALITATIVE ANALYSIS}

This section presents an in-depth and qualitative analysis of metaphors for severe mental disorders (5.1) and metaphors for professional practice in mental healthcare (5.2), the two largest categories found in our balanced corpus.

\subsection{METAPHORS FOR SEVERE MENTAL DISORDERS}

Four main types of metaphor conceptualizing the target domain of MENTAL DISORDER were detected: (a) MENTAL DISORDER IS A LIVING ENTITY, (b) MENTAL DISORDER IS DARKNESS; (c) MENTAL DISORDER IS DESCENT; and (d) MENTAL DISORDER IS A CONTAINER. These are presented and exemplified below. ${ }^{4}$

Firstly, the most prevalent metaphor for this target domain was MENTAL DISORDER IS A LIVING ENTITY, used by patients and professionals in all 8 subgroups. Within this metaphor, the mental disorder was mainly conceptualized as a being one could live with, even in a state of normality (6). It is noteworthy that patients also conceptualized the disorder more negatively as a scary or evil being $(7,8)$.

(6) hoy en día hago una vida normalizada, viviendo y conviviendo con mi trastorno obsesivo compulsivo [OCD]

today I live a normal life, living and cohabiting with my obsessive-compulsive disorder

(7) [...] ayuda y mucho no sólo a sacarse de alguna manera estos fantasmas sino, de hecho, a poder mirarlos, observarlos [SCH]

helps a lot not only to somehow get rid of these ghosts but, in fact, to be able to look at them, observe them

(8) [...] repasar los engranajes que articulan mi Alien y su lubricante fundamental [BIP]

[...] review the gears that articulate my Alien and its fundamental lubricant

Secondly, noteworthy were 2 conceptualizations framing an alternative between the mental disorder and its absence (a positive/healthy situation). One conceptualization

\footnotetext{
${ }^{4}$ Examples are presented with a final tag within square brackets indicating the subgroup origin. Keys are the following: [SCH]: schizophrenia; [OCD]: obsessive-compulsive disorder; [BIP]: bipolar disorder; [DEP]: depression; [PST]: psychiatrist; [PSL]: psychologist; [SED]: social educator; [NUR]: nurse.
} 
was perceptual and conveyed the disorder as a kind of obscurity: darkness (9), fog (10) or shadow (11). Darkness was usually associated with being in an enclosed and dark location, typically a pit (12). The positive alternative was light, which helped to dispel the darkness (13). In specific circumstances darkness even was embodied and personified (14), in a way related to the target domain of DISORDER IS A LIVING ENTITY.

(9) debo intentar levantar el ánimo para no volver a caer en esa oscuridad [DEP] I must try to lift my spirits so I don't fall back into that darkness.

(10) sólo vemos una espesa niebla [OCD] we can only see a thick fog

(11) la sombra siempre está ahí. [DEP] the shadow is always there

(12) Un pozo oscuro donde apenas puede verse un rayito de luz. [OCD] A dark pit where you can barely see a ray of light.

(13) Pero hay que pensar que después de la tormenta sale el sol. [SCH] But you have to think that after the storm the sun comes out.

(14) La sombra que te llama hacia la soledad. [DEP] The shadow that calls you to solitude.

The second important conceptualization proposing an alternative between the mental disorder and its absence was experiential: the feeling of falling into the situation of illness (15), which, as seen above, was compatible with being in a dark place (16). The positive alternative was ascent $(17,18)$, to escape the place that one fell into. When suffering and release alternated, these were lexicalized in terms of ups and downs (19) or relapses (20), which in Spanish are termed recaidas, literally, "re-falls".

(15) volvernos a levantar cuando caemos, porque es seguro que habrá caídas [OCD] to stand up again when we fall, because there will certainly be falls

(16) debo intentar levantar el ánimo para no volver a caer en esa oscuridad [DEP] I must try to lift my spirits so I don't fall back into that darkness

(17) Quiero volver a estar arriba. [SCH] I want to get back on top.

(18) Que podía tocar el cielo con las manos. [SCH] That I could touch the sky with my hands.

(19) no se pasa nada bien los momentos de altibajos. [BIP] you don't have a good time with the ups and downs.

(20) Así disminuye la probabilidad de recaídas. [BIP] This decreases the likelihood of backsliding

Note that McMullen \& Conway (2002) and Charteris-Black (2012) found that the 2 conceptualizations described above (which they formulate as DEPRESSION IS DARKNESS and DEPRESSION IS DESCENT) were among the most characteristic conceptualizations of depression. Our work therefore confirms the relevance of both 
source domains to conceptualize all 4 severe mental disorders, i.e., not only depression but also schizophrenia, bipolar disorder and OCD.

Another pervasive type of metaphor was based on the CONTAINER image schema, mainly MENTAL DISORDER IS A CONTAINER and the PATIENT IS A CONTAINER. For the MENTAL DISORDER IS A CONTAINER, the disorder was conceptualized as a location enclosing the patient that was oppressive and difficult to escape from, e.g. a cave (21) or a pit (22). This metaphor was used in conjunction with the DARKNESS and DESCENT metaphors, as can be seen from the examples.

(21) Porque cuando se está al fondo de la cueva, no se ve la luz que viene del exterior y por tanto el camino hacia la salida [OCD]

Because when you are at the bottom of the cave, you do not see the light coming from outside and therefore the way out

(22) Las alegrías son tan fugaces, que apenas iluminan un segundo el pozo en el que me encuentro [DEP]

Joys are so fleeting, that they barely illuminate for a second the pit in which I find myself

By the second main type of CONTAINER metaphors, the PATIENT was conceptualized either as a receptacle of negative emotions or thoughts conveyed by the disorder (23) or as an enclosed space (24).

(23) la intrusión de pensamientos no deseados y recurrentes [OCD] the intrusion of unwanted and recurring thoughts

(24) Al pensar en mí, me imaginaba una crisálida frágil encerrada en su pequeño mundo [SCH] Thinking of myself, I imagined a fragile chrysalis locked in its little world

Charteris-Black (2012) also found that 'containment and constraint metaphors' (in his terms) were among the main metaphors of depression. Therefore, our work again confirms that container metaphors are used not only to conceptualize major depression but also the rest of the main severe mental disorders.

Another interesting metaphor which we found in all patient types was that of the SPLIT-SELF, whereby patients conceptualized themselves as a divided entity (25) or as coexisting personae (26). In these conceptualizations, the subject was the healthy persona and the other self/part of the self was the ill persona (27). This metaphor was described by Lakoff \& Johnson (1999: 276) as "the scattered self metaphor". The experiencer as a fragmented entity has been related to depression (Demjén, 2011; Coll-Florit et al., 2021) and schizophrenia (Coll-Florit et al., 2019). It has also been studied in non-clinical contexts (e.g. in meditative practices, Silvestre-López and Navarro, 2017: 42). This points to a metaphor that might be quite conventional to conceptualize the self as in (26), but more vividly highlighting a strong separation between the different selves as in $(25,27)$.

(25) ¿por qué una parte de mí habría de tener menos derechos que la otra? [SCH] why should one part of me have fewer rights than the other?

(26) Quizá ya estoy demasiado acostumbrado a vivir conmigo mismo [OCD] Maybe I'm too used to living with myself 
(27) No quería salir al exterior, tenía mucho miedo de mí misma [BIP]

I didn't want to go outside, I was too afraid of myself

To conclude this section, we address the two main conceptualizations of the life of the patient as a process: LIFE OF PATIENT IS A WAR and LIFE OF PATIENT IS A JOURNEY, which are the most frequent metaphors of our corpus in absolute terms. Since such metaphors are typically used to conceptualize conflictive and/or long-term processes, they are very frequently used to talk about a life lived with an illness (Semino et al., 2017, 2018).

All four patient types represented in our corpus referred to their life as a difficult journey (28), where what mattered most was to move forward (29), neither stopping nor going back. Situations were stages to go through (30) or obstacles to overcome (31). It was important not to travel alone, and some patients said that they blogged to ensure they were accompanied (32). It is well known that JOURNEY metaphors are typically used to talk about processes with a goal (conceptualized as the destination); nevertheless, in our corpus patients did not usually make specific reference to the destination, rather, the purpose of the journey was to improve (33) or find a way out (34).

(28) Todo se te hace cuesta arriba y piensas: “Hasta cuándo durará esto?” [BIP] Everything is uphill and you think, "How long will this last?"

(29) conseguí avanzar en un proceso que todavía hoy dura [BIP] I managed to move forward in a process that continues to this day

(30) Si estáis pasando por una depresión, sobre todo no os aisléis ni permanezcáis solos, porque se pasa muy mal [DEP] If you are going through a depression, above all do not isolate yourself or remain alone, because that's very bad

(31) la sombra se pone por el medio, y me tropiezo. [DEP] the shadow gets in the way, and I stumble.

(32) Un día les diré que quienes me acompañan en mi viaje son justamente ustedes y por ese motivo les escribo [OCD] One day I will tell you that those who accompany me on my journey are precisely you and for that reason I am writing to you

(33) Yo solo sigo mi camino, que es el de mejorarme a mí [OCD] I just go my way, which is to make myself better

(34) el camino hacia la salida [OCD] the way out

War metaphors, as pointed out above, were often used to conceptualize conflict situations, which is the case when living with a disorder, with the patient and the disorder as, typically, the contenders. In some cases, such a prototypical fight was confirmed (35) but in many other cases no enemy was specified or the fight was simply that of carrying on living (36,37), as reflected in JOURNEY metaphors. A remarkable feature of our corpus was that patients also signalled discrimination and stigma (38) as well as medical treatment (39) as enemies. In this way, other constraining and disabling aspects of life beyond the disorder itself were highlighted. 
(35) vencer el toc $[\mathrm{OCD}]$ beat the $O C D$

(36) las armas de combate que me ayudan a seguir día a día [OCD] the combat weapons that help me to carry on day after day

(37) Esta lucha por seguir la vida agota [DEP] This struggle to continue living is exhausting

(38) Ahora son otras mis inquietudes; y son, sobre todo, luchar contra el estigma y el autoestigma en salud mental [SCH] I now have other concerns; and they are, above all, fighting stigma and self-stigma in mental health

(39) Demasiada medicación que te deja tocada y hundida [BIP] Too much medication that defeats you

Our analysis shows that war and journey metaphors were not only used to conceptualize physical illness but also mental conditions and, furthermore, that these metaphors were used by people with the 4 most common severe mental disorders. Moreover, in line with Semino et al. (2017), our results show that use of war and journey metaphors can be both empowering and disempowering. From our corpus, consistent with Flusberg et al. (2018), it could be inferred that travel scenarios (see Musolff (2006) for the notion of scenario) are empowering when the patient is in charge of the journey, but not otherwise; and, in turn, war scenarios trigger a sense of threat and fear when the disease is the enemy, thus they are demotivational when patients are reduced to battlefields, but may also provoke solidarity or may be a way of attracting attention, changing beliefs and taking action.

\subsection{METAPHORS FOR PROFESSIONAL PRACTICE IN MENTAL HEALTHCARE}

Metaphors of medicine and professional treatment appeared primarily in a statistically significant way in texts written by professionals (cf. Section 4). The predominant metaphors conceptualized the blogger's own profession in terms of 3 main source domains: JOURNEY $(40,41)$, WAR $(42,43)$ and POWER (44). Thus, WAR and JOURNEY metaphors featured again, this time to conceptualize professional practice in mental healthcare.

(40) Sigo transitando por espacios inexplorados, no porque sean inaccesibles sino porque pocos quieren acercarse a ellos. [SED]

I continue to walk through unexplored spaces, not because they are inaccessible but because few want to go near them.

(41) Gracias por caminar a mi lado [NUR] Thank you for walking beside me

(42) La psiquiatría social (...) ha atacado con frecuencia a otras orientaciones psiquiátricas [PST] Social psychiatry (...) has often attacked other psychiatric orientations

(43) quiero mostrar mi apoyo a esta campaña porque esta es mi lucha y mi sueño personal y a nivel profesional [NUR] 
I want to show my support for this campaign because this is my struggle and my personal and professional dream

(44) saber que estas sentencias, cuando provienen de un cierto orden jerárquico, pueden adquirir la categoría de mandato [PSL]

to know that these judgements, when they come from a certain hierarchical order, can acquire the status of a mandate

As for POWER, this source domain was encountered in all 4 professional subgroups. When a professional practice was talked about critically as a REPRESSIVE POWER, this assessment typically originated with a blogger from a different profession; social educators, for instance, often metaphorized psychiatry as a crime (45), usually when challenging overmedication (46).

(45) La policía médica actúa impunemente, impone sus tratamientos bajo engaños, bajo coacción, coerción o chantaje o bajo la desinformación sistemática [SED]

The medical police act with impunity, imposing their treatments through deception, coercion or blackmail or through systematic disinformation

(44) sensibilidades diversas que han sido reprimidas por fármacos. [SED] various sensitivities that have been stifled by drugs

This metaphor evidences certain tensions and criticisms between the different ways of approaching professional practice in mental health. In particular, social educators in our corpus consider that psychiatric practice and the medical system tend to limit the patient's capacity for agency, thus they call for more person-focused than problem-focused models. These results are consistent with Correa-Urquiza et al. (2020), a study based on a Twitter corpus about the Mad Pride Day, which shows that one of the most recurrent metaphors of mental health activists is the conceptualization of psychiatry as a repressive power. The criticisms, in general, probably emerged because the textual genres of blogging and microblogging online allow for freer expression than more formal genres (Kotliar, 2016; Seale et al., 2010).

\section{CONCLUSIONS}

We have presented the building and the metaphor annotation of a corpus of firstperson accounts of patients with severe mental health disorders and mental healthcare professionals, published in blogs. This work represents the first attempt to address, in an integrated manner, the analysis of CMs for different types of mental health patients and mental healthcare professionals, and to conduct intergroup and intragroup comparisons.

Quantitative results show that, in general terms, patients and professionals differ in the topics they use in their metaphors: patients produce a greater volume of metaphors directly related to the severe mental disorder (including the target domains of MENTAL DISORDER, PATIENT and LIFE OF PATIENT), whereas professionals, although they also produce metaphors for the disorder and the related experiences, use mainly metaphors related to their profession. In other words, each subgroup mainly uses metaphorical language to discuss their experiences as lived personally and firsthand. This probably reflects the genre of blogging and first-person writing, i.e., discourse in which the authors spontaneously discuss the issues that most affect them. Regarding similarities between the patient and professional groups, noteworthy is the fact that journey and war 
metaphors are predominant in the writings of the two groups in coping with living with a disorder and with being a mental health professional.

Regarding the intragroup analysis of patients, interestingly, no statistically significant differences were found by diagnosis (schizophrenia, bipolar disorder, major depression or OCD) in the volume of metaphors produced. Likewise, regarding the type of metaphor, the metaphors in which the disorder was conceptualized as a LIVING ENTITY, DARKNESS, DESCENT or a CONTAINER were predominant and were common to all four mental disorder subgroups, while the SPLIT-SELF metaphor was also used by all the patients. Thus, irrespective of the specific diagnosis, these findings point to common conceptualizations of mental suffering.

As for the intragroup analysis of professionals, statistically significant differences were found in the volume of metaphors used by social educators and nurses (largest and smallest, respectively, of the four subgroups of professionals). Finally, qualitative analysis revealed certain tensions and criticisms between different mental health professionals, especially in the social educators' conceptualization of psychiatry as a repressive power. This further confirms the blog as a genre allowing one to express one's own thoughts, even polemical or critical thoughts.

\section{REFERENCES}

Barcelona, Antonio. 1986. «On the concept of depression in American English: A cognitive approach». Revista Canaria de Estudios Ingleses, 12: 7-34.

Boylstein, Craig, Maude Rittman and Ramon Hinojosa. 2007. «Metaphor shifts in stroke recovery». Health Communication, 21 (3): 279-287. DOI: 10.1080/10410230701314945

Charteris-Black, Jonathan. 2012. «Shattering the Bell Jar: Metaphor, Gender, and Depression». Metaphor and Symbol, 27 (3): 199-216. DOI: 10.1080/10926488.2012.665796

Climent, Salvador and Marta Coll-Florit (2017). «La metáfora conceptual en el discurso psiquiátrico sobre la esquizofrenia [Conceptual metaphor in psychiatric discourse on schizophrenia]». Ibérica, 34: 187-208.

Coll-Florit, Marta, Salvador Climent, Martín Correa-Urquiza, Eulàlia Hernández, Antoni Oliver and Asun Pié (2018). «MOMENT: Metáforas del trastorno mental grave. Análisis del discurso de personas afectadas y profesionales de la salud mental [MOMENT: Metaphors of severe mental disorder. Discourse analysis of affected people and mental health professionals]». Procesamiento del lenguaje natural, 61: 139-142.

Coll-Florit, Marta and Salvador Climent (2019). «A new methodology for conceptual metaphor detection and formulation in corpora. A case study on a mental health corpus». SKY Journal of Linguistics, 32: 43-74.

Coll-Florit, Marta, Xavier Miranda and Salvador Climent (2019). «Metáforas de la esquizofrenia: Un estudio sobre el discurso de afectados y profesionales [Metaphors of schizophrenia. Discourse analysis of sufferers and professionals]». Revista Española de Lingüistica Aplicada/Spanish Journal of Applied Linguistics, 32(1): 1-31.

Coll-Florit, Marta, Salvador Climent, Marco Sanfilippo and Eulàlia Hernández (2021). «Metaphors of Depression. Studying First Person Accounts of Life with Depression Published in Blogs». Metaphor and Symbol, 36(1): 1-19, DOI: 10.1080/10926488.2020.1845096

Correa-Urquiza, Martín, Asun Pié, Marta Coll-Florit, Eulàlia Hernández and Salvador 
Climent (2020). «Orgullo loco y metáforas para una disidencia: un análisis lingüístico y simbólico [Mad pride and metaphors for dissidence: a linguistic and symbolic analysis]». Salud Colectiva, 16:e2886. DOI: 10.18294/sc.2020.2886

Demjén, Zsófia. 2011. "Motion and conflicted self metaphors in Sylvia Plath's "Smith Journal"». Metaphor and the Social World, 1 (1): 7-25. DOI: 10.1075/msw.1.1.02dem

Demjén, Zsófia., Agnes Marszalek, Elena Semino and Filippo Varese. 2019. «Metaphor framing and distress in lived-experience accounts of voice-hearing». Psychosis, 11 (1): 16-27. DOI: 10.1080/17522439.2018.1563626

Fahlenbrach, Kathrin. 2017. «Audiovisual metaphors and metonymies of emotions and depression in moving images». In Francesca Ervas, Elisabetta Gola and Maria Grazia Rossi (eds.) Metaphor in Communication, Science and Education, pp. 95118, Berlin/Boston, MA: De Gruyter.

Flusberg, Stephen J., Teenie Matlock and Paul H. Thibodeau. 2018. «War metaphors in public discourse». Metaphor and Symbol, 33 (1): 1-18. DOI: 10.1080/10926488.2018.1407992

Forceville, Charles and Sissy Paling. 2018. "The metaphorical representation of DEPRESSION in short, wordless animation films». Visual Communication, 0 (0): 1-21. DOI: $10.1177 / 1470357218797994$

Gibbs Jr, Raymond W. and Heather Franks. 2002. «Embodied metaphor in women's narratives about their experiences with cancer». Health Communication, 14 (2): 139-165. DOI: 10.1207/S15327027HC1402_1

Goering, Elizabeth M. 2015. «Metaphors as mirrors into what it means to be diabetic». In Elizabeth M. Goering and Marta Antón (eds.) Understanding Patients' Voices. A Multi-method Approach to Health Discourse, pp. 71-86. Amsterdam: John Benjamins.

Gustafsson, Anna W., Charlotte Hommerberg and Anna Sandgren. 2020. «Coping by metaphors: the versatile function of metaphors in blogs about living with advanced cancer». Med Humanit., 46 (3): 267-277. DOI: 10.1136/medhum-2019011656.

Hommerberg, Charlotte, Anna W. Gustafsson and Anna Sandgren. 2020. «Battle, Journey, Imprisonment and Burden: patterns of metaphor use in blogs about living with advanced cancer». BMC Palliat Care, 19: 59. DOI: 10.1186/s12904-02000557-6

Hookway, Nicholas. 2008. «"Entering the blogosphere”: Some strategies for using blogs in social research». Qualitative Research, 8: 91-113. DOI: $10.1177 / 1468794107085298$

Knapton, Olivia. 2016. «Dynamic conceptualizations of threat in obsessive-compulsive disorder (OCD)». Language and Cognition, 8 (1): 1-31. DOI: 10.1017/langcog.2015.18

Knapton, Olivia and Gabriella Rundblad. 2018. «Metaphor, discourse dynamics and register: applications to written descriptions of mental health problems». Text \& Talk, 38 (3): 389-410. DOI: 10.1515/text-2018-0005

Kotliar, Dan M. 2016. «Depression narratives in blogs: A collaborative quest for coherence». Qualitative Health Research, 26 (9): 1203-1215. DOI: $10.1177 / 1049732315612715$

Kövecses, Zoltan. 2002. Metaphor: A practical introduction. New York: Oxford University Press.

Lakoff, George and Mark Johnson. 1980. Metaphors we live by. Chicago: University of Chicago Press. 
Lakoff, George and Mark Johnson. 1999. Philosophy in the flesh. The embodied mind and its challenge to western thought. New York: Basic Books.

Lakoff, George, Jane Espenson and Alan Schwartz. 1991. Master Metaphor List. Draft 2nd. ed. Technical Report, Cognitive Linguistics Group. Berkeley, CA: University of California, Berkeley.

Magaña, Dalia and Teenie Matlock. 2018. «How Spanish speakers use metaphor to describe their experiences with cancer». Discourse \& Communication, 12 (6): 627-644. DOI:10.1177/1750481318771446

Markham, Annette, Elizabeth Buchanan and AoIR Ethics Working Committee. 2012. Ethical decision-making and Internet research. Recommendations from the AoIR Ethics Working Committee (Version 2.0). Retrieved from: http://www.aoir.org/reports/ethics2.pdf

McMullen, Linda M. 2008. «Putting it in context: Metaphor and psychotherapy». In Raymond W. Gibbs (ed.) The Cambridge Handbook of Metaphor and Thought, pp. 397-411. Cambridge: Cambridge University Press.

McMullen, Linda M. and John B. Conway. 2002. «Conventional metaphors for depression». In Susan R. Fussell (ed.) The Verbal Communication of Emotions, pp. 167-181. Mahwah, NJ: Erlbaum.

Mould, Tracy J., Lindsay G. Oades and Trevor P. Crowe. 2010. «The use of metaphor for understanding and managing psychotic experiences: A systematic review». Journal of Mental Health, 19 (3): 282-293. DOI: 10.3109/09638231003728091

Musolff, Andreas. 2006. "Metaphor scenarios in public discourse». Metaphor and Symbol, 21(1): 23-38. DOI: 10.1207/s15327868ms2101_2

Navarro i Ferrando, Ignasi. 2017. «Conceptual metaphor types in oncology: Cognitive and communicative functions». Ibérica, 34: 163-186.

Navarro i Ferrando, Ignasi. 2021. «Metaphorical concepts and their cognitive functions in medical discourse: research papers vs. press articles». Journal of English for Specific Purposes at Tertiary Level, 9(1): 150-174. DOI: 10.18485/esptoday.2020.8.1.1

O'Brien, Mary R. and David Clark. 2012. «Unsolicited written narratives as a methodological genre in terminal illness: Challenges and limitations». Qualitative Health Research, 22: 274-284. DOI: 10.1177/1049732311420737

Ogarkova, Anna and Cristina Soriano. 2014. "Variation within universals: The "metaphorical profile" approach to the study of ANGER concepts in English, Russian and Spanish». In Andreas Musolff, Fiona MacArthur and Giulio Pagani (eds.), Metaphor and Intercultural Communication, pp. 93-116. London: Bloomsbury.

Pragglejaz Group. 2007. «MIP: A method for identifying metaphorically used words in discourse». Metaphor and Symbol, 22 (1): 1-39. DOI: 10.1080/10926480709336752

Reali, Florencia, Tania Soriano and Daniela Rodríguez. 2016. «How we think about depression: The role of linguistic framing». Revista Latinoamericana de Psicología, 48 (2): 127-136. DOI: 10.1016/j.rlp.2015.09.004

Reisfield, Gary M. and George R. Wilson. 2004. «Use of metaphor in the discourse on cancer». Journal of Clinical Oncology, 22(19): 4024-4027. DOI:10.1200/JCO.2004.03.136

Rossetti, Ileana, Paolo Brambilla, and Costanza Papagno. 2018. «Metaphor Comprehension in Schizophrenic Patients». Frontiers in psychology, 9: 670. DOI: 10.3389/fpsyg.2018.00670

Seale, Clive, Jonathan Charteris-Black, Aidan MacFarlane and Ann McPherson. 2010. 
«Interviews and internet forums: A comparison of two sources of qualitative data». Qualitative Health Research, 20 (5): 595-606. DOI: $10.1177 / 1049732309354094$

Semino, Elena. 2008. Metaphor in discourse. Cambridge: Cambridge University Press.

Semino, Elena, Zsófia Demjén, Jane Demmen, Veronika Koller, Sheila Payne, Andrew Hardie and Paul Rayson. 2017. "The online use of Violence and Journey metaphors by patients with cancer, as compared with health professionals: a mixed methods study». BMJ Supportive \& Palliative Care, 7 (1): 60-66. DOI: 10.1136/bmjspcare-2014-000785

Semino, Elena, Zsófia Demjén, Andrew Hardie, Sheila Payne and Paul Rayson. 2018. Metaphor, cancer and the end of life: A corpus-based study. London: Routledge.

Schoeneman, Thomas J., Katherine A. Schoeneman and Selona Stallings. 2004. "The black struggle": Metaphors of depression in Styron's Darkness Visible». Journal of Social and Clinical Psychology, 23 (3): 325-346. DOI: 10.1521/jscp.23.3.325.35454

Shoeneman, Thomas J., Janel Putnam, Ian Rasmussen, Nina Sparr and Stephanie Beecham. 2012. "A Fire in the Blood': Metaphors of Bipolar Disorder in Jamieson's An Unquiet Mind». Journal of Medical Humanities, 33: 185-205.

Silvestre-López, Antonio J. 2016. «The discourse of mindfulness: What language reveals about the mindfulness experience». In Pilar Ordóñez-López and Nuria Edo-Marzá (eds.) Medical discourse in professional, academic and popular settings, pp. 173198. Bristol, UK: Multilingual Matters.

Silvestre-López, Antonio J. and Ignasi Navarro i Ferrando. 2017. «Metaphors in the conceptualization of meditative practices». Metaphor and the Social World, 7 (1): 26-46. DOI: 10.1075/msw.7.1.03sil

Steen, Gerard J., Aletta G. Dorst, J. Berenike Herrmann, Anna Kaal and Tina Krennmayr. 2010a. «Metaphor in Usage». Cognitive Linguistics, 21 (4): 765-796.

Steen, Gerard J., Aletta G. Dorst, J. Berenike Herrmann, Anna Kaal, Tina Krennmayr and Tryntje Pasma. 2010b. A method for linguistic metaphor identification: From MIP to MIPVU. Amsterdam: John Benjamins.

Stefanowitsch, Aanatol. 2006. «Words and their metaphors. A corpus-based approach». In Anatol Stefanowitsch and Stefan Th. Gries (eds.) Corpus-based approaches to metaphor and metonymy, pp. 61-105. Berlin and New York: Mouton de Gruyter.

Tay, Dennis. 2016. «Using metaphor in healthcare: Mental health». In Zófia Demjén and Elena Semino (eds.) The Routledge Handbook of Metaphor and Language, pp. 371-385. London: Routledge.

Varela Suárez, Ana. 2020. «El empleo del lenguaje figurado en el discurso de personas con demencia». Revista signos, 53 (102): 272-293. DOI: 10.4067/S071809342020000100272

World Health Organization. 2018. International classification of diseases for mortality and morbidity statistics (11th Revision). Retrieved from: https://www.who.int/classifications/icd/en/ 